\title{
Aplikasi Sari Daun Kelor Sebagai Zat Pengatur Tumbuh Organik Terhadap Pertumbuhan Dan Kadar Klorofil Tanaman Kedelai (Glycine max (L.) Merr.)
}

\author{
Fauziah Laily Amriyanti ${ }^{1}$, Purity Sabila A. ${ }^{2}$ \\ 1) Mahasiswa Prodi Biologi FMIPA Universitas PGRI Adi Buana Surabaya \\ 2) Staf Pengajar Prodi Biologi FMIPA Universitas PGRI Adi Buana Surabaya \\ Email: fauzialaily12@gmail.com ${ }^{1}$, puritysabila@unipasby.ac.id ${ }^{2}$
}

\begin{abstract}
Soybean as a protein sources can fill the needs of public's food increasily but the production in this country is still low. Therefore, cultivation efforts are needed to improve the growth and development of soybean plants. Some factors that are sufficient to influence the plant growth process are nutrient supply, water availability, sunlight, air temperature, oxygen and growth regulators. Plant Growth Regulator (PGR) that can be used is moringa leaves as a source of cytokinins. Cytokinin serves stimulating cell division, postpone the process of aging plants, and spur growth budding. This study aims to determine the effect of giving plant growth organic made by moringa leaves with 2 control, which are negative control (0\%) and positive control (cytokinin synthetic solution) and 3 treatment at concentration of P1 (10\%), P2 (20\%), P3 (30\%) to increase the growth soy plants and to know the concentration optimally of any treatment given. This research using the completely randomized design (CRD) with 5 treatment and 5 replicate. The results were analyzed using the ANOVA test followed by the LSD/BNT test and the Duncan test. The results showed that the application of organic PGR made from Moringa leaves had a significant effect ( $P$ $<0.05)$ on growth (plant height and number of leaves) and chlorophyll content in soybean plants had optimal concentrations at $30 \%$ concentration.
\end{abstract}

Keywords: moringa leaves, cytokinin, soybean plants, plant growth regulator.

\section{PENDAHULUAN}

Salah satu komoditas pertanian yang penting dalam penyediaan bahan pangan dan pakan adalah kedelai (Glycine max (L.) Merr.). Kedelai sangat penting untuk peningkatan kesehatan dan gizi masyarakat karena mengandung sumber protein tinggi dan dapat diolah menjadi berbagai bahan industri olahan pangan seperti tahu, tempe, kecap dan masih banyak lagi.

Untuk memenuhi kebutuhan kedelai yang terus meningkat maka produksi tanaman kedelai harus terus ditingkatkan. Strategi budidaya yang tepat diperlukan untuk meningkatkan produksi tanaman kedelai. Salah satunya adalah dengan menggunakan zat pengatur tumbuh (ZPT) yang tepat sehingga dapat mempengaruhi pertumbuhan dan perkembangan tanaman. Selain ZPT, faktor yang dapat mempengaruhi pertumbuhan tanaman adalah persediaan makanan atau unsur hara yang cukup, cahaya matahari, ketersediaan air, suhu udara dan oksigen.

Zat Pengatur Tumbuh (ZPT) ada yang berasal dari tanaman itu sendiri (zat pengatur tumbuh endogen) dan bersifat alami, ada juga yang berasal dari luar tanaman tersebut dan disebut sintetis. Salah satu zat pengatur tumbuh (ZPT) yang dapat digunakan yaitu daun kelor, yang mengandung sitokinin untuk mendorong terjadinya pembelahan sel, pertumbuhan, perkembangan dan menunda penuaan sel pada tanaman (Rahman dkk, 2017). Menurut (Taiz dan Zeiger, 2002), sitokinin dalam menstimulasi sintesis protein bekerja sangat baik dan berperan dalam kontrol siklus sel, sekaligus merangsang aktivitas pembelahan sel dan sangat efektif dalam meningkatkan inisiasi tunas.

Penelitian yang dilakukan oleh Emongor (2015) menyebutkan bahwa ekstrak daun kelor dengan konsentrasi 20$30 \%$ berdasarkan variabel lebar daun, tinggi tanaman, jumlah daun, dan jumlah klorofil dapat meningkatkan pertumbuhan tanaman kacang panjang. Ekstrak daun kelor mengandung hormon sitokinin alami seperti zeatin, dihydrozeatin dan isopentyladenine. Selain itu, daun kelor mengandung protein, mineral, vitamin, asam amino esensial, glucosinolates, isothiocyanates dan fenolat yang dapat memicu pertumbuhan tanaman (Culver dkk, 2012). 
Tujuan penelitian ini adalah untuk mengetahui apakah ekstrak daun kelor berpengaruh terhadap pertumbuhan tanaman kedelai (Glycine max (L.) Merr.) pada berbagai konsentrasi yang berbeda serta menentukan jumlah kadar klorofil pada daun tanaman kedelai. Hasil penelitian ini dapat menjadi penunjang informasi dalam memanfaatkan bahan zat pengatur tumbuh organik untuk pertumbuhan tanaman kedelai.

\section{METODE PENELITIAN \\ Waktu dan Tempat}

Penelitian ini dilaksanakan di Balai Penyuluhan Pertanian (BPP) Porong, Kabupaten Sidoarjo, bulan Maret-Mei 2019.

\section{Bahan dan Alat}

Bahan dan alat yang digunakan pada penelitian ini meliputi benih kedelai varietas grobogan, daun kelor, tanah, sekam padi, kompos, air, akuades, alkohol 96\%, es batu dan tissue, polybag, kertas saring, handscoon, benang, penggaris, termos es, blender, timbangan analitik, gembor air, lumpang dan alu porselein, pipet tetes, tabung reaksi, gelas ukur, cuvet, centrifuge dan spectrofotometer genesys 20.

\section{Rancangan Penelitian}

Penelitian ini menggunakan Rancangan Acak Lengkap (RAL), terdapat 2 kontrol yaitu kontrol positif (Kp) dengan pemberian sitokinin sintetis dan kontrol negatif $(\mathrm{Kn})$ dengan pemberian sari daun kelor $(0 \%)$, kemudian 3 perlakuan sari daun kelor dengan pemberian varian konsentrasi yang berbeda yaitu P1 (10\%), P2 (20\%), P3 $(30 \%)$ yang diaplikasikan ke tanaman kedelai. Terdapat 25 sampel yang diamati (5 kali ulangan ke masing-masing perlakuan).

\section{Prosedur Penelitian}

Biji tanaman kedelai yang digunakan berasal dari varietas Grobogan. Penanaman kedelai dilakukan pada polybag. Pemasangan ajir sangat penting agar terhindar dari tanaman kedelai yang roboh.
Pemberian ZPT dilakukan setiap satu minggu sekali hingga panen, kemudian dilakukan pengukuran hasil tinggi tanaman dan jumlah daun.

Pemanenan kedelai dilakukan pada tanaman berumur 83 HST. Parameter yang digunakan pada saat pemanenan yaitu mengukur tinggi tanaman kedelai menggunakan bantuan benang kemudian diukur menggunakan penggaris dalam satuan $(\mathrm{cm})$ mulai dari pangkal batang sampai ujung daun yang paling tinggi dan jumlah daun dihitung dari setiap tanaman kedelai. Analisis kandungan klorofil dilakukan pada hari terakhir setelah panen. Bahan analisis klorofil menggunakan daun dari tanaman kedelai yang sudah diberi dengan sari daun kelor kemudian diuji menggunakan spektrofotometer UV-Vis pada $\lambda 649$ dan $665 \mathrm{~nm}$. Adapun kadar klorofil yang diamati adalah kadar klorofil total.

\section{Analisis Data}

Data dianalisis menggunakan uji statistika, yaitu dengan analisis varian Oneway ANOVA dengan taraf signifikan 5\%. kemudian dilanjutkan uji Duncan untuk mengetahui konsentrasi yang paling optimal diantara lima perlakuan.

\section{HASIL DAN PEMBAHASAN}

Aplikasi zat pengatur tumbuh organik berbahan baku daun kelor menunjukkan adanya pengaruh yang berbeda nyata terhadap pertumbuhan (tinggi tanaman dan jumlah daun) dan kadar klorofil tanaman kedelai.

\section{Tinggi Tanaman}

Berdasarkan analisis data diketahui bahwa tinggi tanaman dengan pemberian berbagai konsentrasi zat pengatur tumbuh organik terdapat perbedaan signifikan diantara ke lima perlakuan dari uji analisis varian $(0,05)$ karena $p<0,05$. Maka dilakukan uji lanjut untuk mengetahui beda nyata terkecil diantara lima perlakuan pada pertumbuhan tinggi tanaman kedelai (Glycine $\max (\mathrm{L}$.$) Merr.).$ 
Gambar 1 menunjukkan pada kontrol negatif sebesar $70 \mathrm{~cm}$, kontrol positif sebesar $75 \mathrm{~cm}$, pada perlakuan P1 dengan konsentrasi $10 \%$ sebesar $79 \mathrm{~cm}$, pada perlakuan P2 dengan konsentrasi 20\% sebesar $81,6 \mathrm{~cm}$ dan pada perlakuan P3 dengan konsentrasi $30 \%$ sebesar $85,8 \mathrm{~cm}$.

Hasil uji Duncan diketahui bahwa kontrol negative $(\mathrm{KN})$ berbeda nyata dengan perlakuan P1 (10\%), P2 (20\%) dan P3 (30\%), tetapi tidak berbeda nyata dengan kontrol positif (KP), sedangkan KP berbeda nyata dengan $\mathrm{P} 330 \%$, dan kontrol negatif menunjukkan hasil terendah sedangkan konsentrasi terbaik untuk tinggi tanaman kedelai terdapat pada konsentrasi 30\%.

Tinggi tanaman yang tumbuh dengan baik pada konsentrasi 30\% menunjukkan bahwa unsur hara yang dibutuhkan tanaman tersedia dan seimbang. Pemberian ZPT organik berbahan baku daun kelor yang mengandung sitokinin merangsang pembesaran dan pembelahan sel karena sitokinin diproduksi dalam jaringan yang sedang tumbuh aktif khususnya pada akar, selanjutnya diangkut oleh xylem menuju selsel target pada batang sehingga mempengaruhi perpanjangan batang pada tanaman (Intan, 2008; Santoso dan Nursandi, 2002).

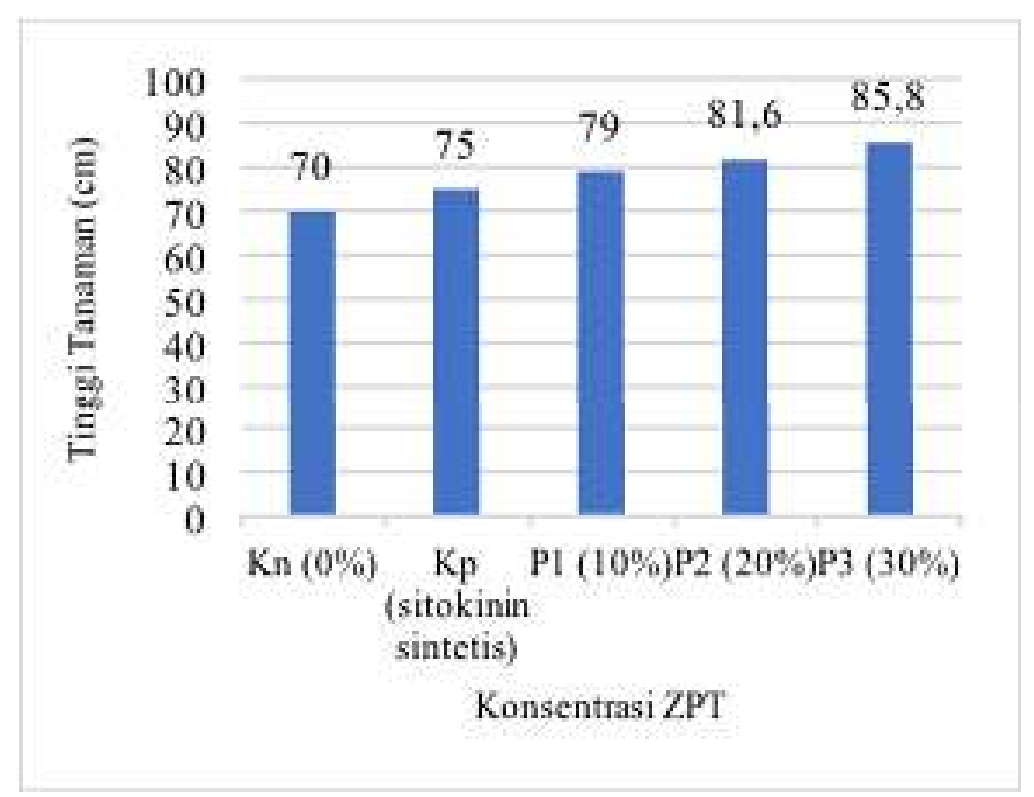

Gambar 1. Rata-rata tinggi tanaman kedelai setelah diberi perlakuan ekstrak daun kelor 
Pemberian sitokinin pada tanaman harus seimbang, karena pada kadar yang terlalu tinggi atau kadar yang terlalu rendah, pertumbuhan tunas menjadi terganggu (George dkk, 2008), sehingga pada P3 dengan konsentrasi $30 \%$, unsur sitokinin yang dibutuhkan oleh tanaman kedelai lebih optimal untuk mempercepat pertumbuhan dibandingkan dengan kontrol negatif $(0 \%)$, kontrol positif (sitokinin sintetis), P1 (10\%) dan P2 (20\%).

Penelitian sebelumnya yang dilakukan oleh Handayani (1999) juga menunjukkan hasil pemberian sitokinin terhadap pertumbuhan manggis sebesar 2 ppm cenderung menghambat pertambahan luas daun, meskipun data juga menunjukkan bahwa sitokinin dapat meningkatkan pertambahan tinggi batang dan jumlah daun.

\section{Jumlah Daun}

Berdasarkan analisis data diketahui bahwa terdapat perbedaan signifikan diantara ke-lima perlakuan dari analisis varian $(0,05)$ karena $\mathrm{p}<0,05$. Maka dilakukan uji lanjut untuk mengetahui beda nyata terkecil diantara lima perlakuan pada pertumbuhan jumlah daun tanaman kedelai.

Gambar 2 menunjukkan bahwa pada kontrol negatif $(\mathrm{KN})$ rata-rata jumlah daun sebanyak 155,2 helai, kontrol positif (KP) sebanyak 168,8 helai, pada perlakuan P1 dengan konsentrasi $10 \%$ sebanyak 170 helai, pada perlakuan $\mathrm{P} 2$ dengan konsentrasi $20 \%$ sebanyak 175,8 helai, pada perlakuan P3 dengan konsentrasi 30\% sebanyak 180,6 helai.

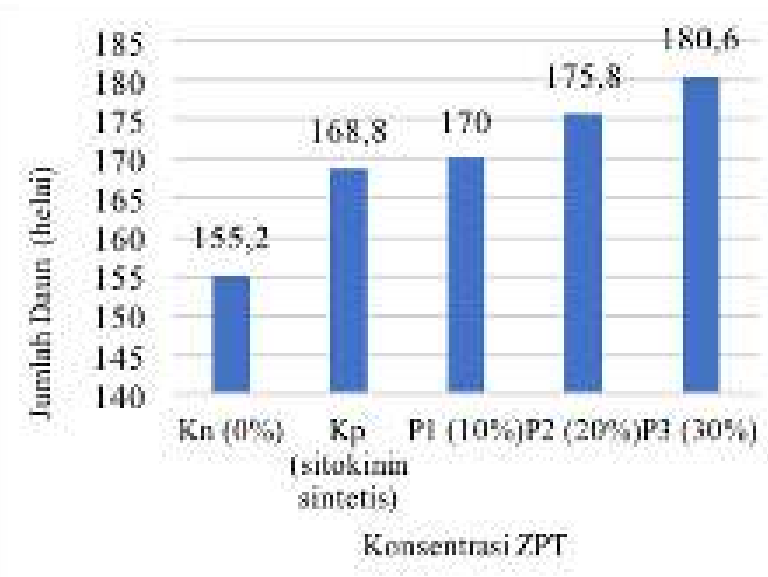

Gambar 2. Rata-rata jumlah daun tanaman kedelai setelah diberi perlakuan ekstra daun kelor

Data uji Duncan diketahui bahwa kontrol negatif (KN) berbeda nyata dengan perlakuan $20 \%$ dan $30 \%$ tetapi tidak berbeda nyata dengan kontrol positif (KP) dan perlakuan $10 \%$ sedangkan KP berbeda nyata dengan perlakuan $20 \%$ dan $30 \%$ tetapi tidak berbeda nyata dengan $\mathrm{KN}$ dan P $10 \%$.

Hidayat (1995) menyebutkan bahwa jumlah daun semakin bertambah diduga karena sel-sel primordia daun mengalami peningkatan pembelahan dan sel ujung batang terdiferensiasi akibat pemberian sitokinin. Sitokinin juga berperan dalam penyimpanan klorofil, pengumpulan asam amino, dan penyimpanan protein dalam daun yang semuanya menunjukkan penundaan proses penuaan daun dengan cara mengatur pembelahan sel dalam daun yang sedang tumbuh (Gardner, 1991; Efroni dkk, 2013).

Pemberian ZPT organik pada P3 dengan konsentrasi $30 \%$ berpengaruh dalam peningkatan jumlah daun pada tanaman kedelai dibandingkan dengan kontrol negatif $(0 \%)$, kontrol positif (sitokinin sintetis), P1 
(10\%) dan P2 (20\%). Hal ini ditunjang dari penelitian sebelumnya yang dilakukan oleh Arnita (2008) yang menunjukkan hasil pemberian sitokinin terhadap tanaman pule pandak sebesar 100 ppm dapat meningkatkan jumlah daun tanaman pule pandak.

\section{Kadar Klorofil}

Berdasarkan analisis data kadar klorofil, diketahui bahwa terdapat perbedaan signifikan diantara ke lima perlakuan dari analisis varian $(0,05)$ karena $p<0,05$. Maka dilakukan uji lanjut untuk mengetahui beda nyata terkecil diantara lima perlakuan pada pertumbuhan jumlah daun tanaman kedelai (Glycine max (L.) Merr.).

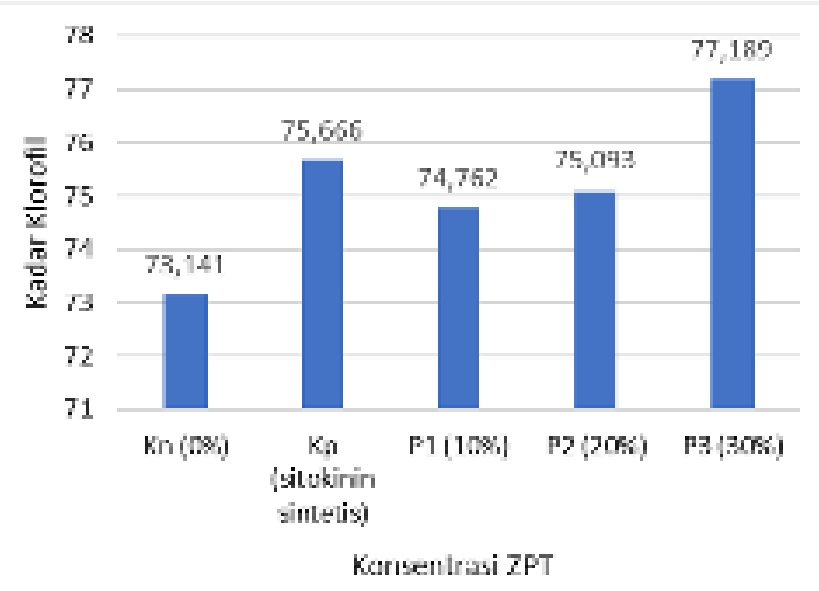

Gambar 3. Rata-rata kadar klorofil total tanaman kedelai setelah diberi ekstrak daun kelor

Berdasarkan gambar 3, pada kontrol negatif sebesar 73,141, kontrol positif sebesar 75,666, pada perlakuan P1 dengan konsentrasi $10 \%$ sebesar 74,762, pada perlakuan P2 dengan konsentrasi 20\% sebesar 75,093, pada perlakuan P3 dengan konsentrasi $30 \%$ sebesar 77,189.

Data hasil uji Duncan diketahui bahwa kontrol negatif berbeda nyata dengan kontrol positif, perlakuan $10 \%, 20 \%$ dan $30 \%$, sedangkan kontrol positif berbeda nyata dengan perlakuan $30 \%$. Kontrol negatif menunjukkan hasil terendah sedangkan konsentrasi terbaik untuk kadar klorofil tanaman kedelai terdapat pada konsentrasi $30 \%$.

Pemberian ekstrak daun kelor pada P3 dengan konsentrasi 30\% berpengaruh dalam peningkatan kadar klorofil pada tanaman kedelai dibandingkan dengan kontrol negatif $(0 \%)$, kontrol positif (sitokinin sintetis), P1 (10\%) dan P2 (20\%). Penelitian yang dilakukan oleh Emongor (2015) juga menyatakan bahwa pemberian ekstrak daun kelor dengan konsentrasi $20-30 \%$ pada daun kacang panjang dapat meningkatkan jumlah klorofil.

Hasil penelitian lain menunjukkan bahwa biosintesis klorofil pada daun terjadi akibat adanya aplikasi sitokinin eksogen (6benzyladenine) dan sitokinin ini berperan dalam penyimpanan protein (asam amino) dan klorofil dalam daun menyebabkan proses penuaan (Gardner dkk, 1991; Kobayashi dkk, 2017).

\section{KESIMPULAN}

Berdasarkan hasil penelitian yang diperoleh, analisis data dan pembahasan maka dapat disimpulkan bahwa:

1. Pemberian ZPT organik berbahan baku daun kelor berpengaruh terhadap peningkatan pertumbuhan tanaman dan kadar klorofil kedelai (Glycine $\max$ (L.) 
Merr.).

2. Konsentrasi yang optimal dari ZPT organik berbahan baku daun kelor terhadap pertumbuhan dan kadar klorofil tanaman kedelai (Glycine max (L.) Merr.) yaitu pada konsentrasi $30 \%$.

\section{UCAPAN TERIMA KASIH}

Terima kasih kepada staf pengajar Biologi FMIPA UNIPA Surabaya dan rekan-rekan penulis yang telah memberikan masukan dan sarannya dalam menyelesaikan penelitian ini.

\section{DAFTAR PUSTAKA}

Arnita, R. 2008. Skripsi. Jurusan Budidaya Pertanian. Fakultas Pertanian. Universitas Sebelas Maret. Surakarta.

Cortleven, A., dan Schmulling, T. 2015. Regulation of chloroplast development and function by cytokinin (Review Paper). Journal of Experimental Botany, 66(16), 49995013. doi.org/10.1093/jxb/erv132

Culver, M., T. Fanuel, dan A. Z. Chiteka. 2012. Effect of Moringa Extract on Growth and Yield of Tomato. Green Journal of Agricultural Sciences. Vol. 2 (5): 207-211.

Davies, P. J. 2010. The plant hormones: Their nature, occurrence, and functions. Department of Plant Biology. Cornell University, Ithaca, New York 14853, USA.

Departemen Pertanian. 2014. Kedelai. Badan Penelitian dan Pengembangan Pertanian. Medan.

Efroni, I., Han, S. K., Kim, H. J., Wu, M. F., Steiner, E., Birnbaum, K. D., Hong, J. C., Eshed, Y., \& Wagner, D. 2013. Regulation of leaf maturation by chromatin-mediated modulation of cytokinin responses. Dev. Cell, 24, 438445.

Emongor, V.E. 2015. Effects of Moringa (Moringa oleifera) leaf extract on growth, yield and yield components of snap beans (Phaseolus vulgaris). British Journal of Applied Science and Technology. 6(2):114-122.

Gardner, F.P., Pearce, R.B., dan Mitchell

R.L. 1991. Fisiologi Tanaman Budidaya. Penerjemah Susilo, $\mathrm{H}$ dan Pendamping Subiyanto. Cetakan Pertama. Penerbit Universitas Indonesia Press, Jakarta.

Handayani, I. 1999. Pengaruh Konsentrasi Sitokinin dan Triakontanol Pada Pertumbuhan Manggis (Garcinia mangostana Hasil Penyambungan. Skripsi. Jurusan Budidaya Pertanian. Fakutas Pertanian. Institut Pertanian Bogor. 53 hal.

Hardjowigeno, M. 2003. Pemupukan. Akademika Pressindo. Jakarta.

Hidayat, 1995. Fisiologi Tanaman Budidaya Tropik. Gadja Mada. University Press, Yogyakarta.

Intan, R, D, A. 2008. Peranan dan Fungsi Fitohormon Bagi Pertumbuhan Tanaman. Makalah. Fakultas Pertanian. Universitas Pajajaran. 43 hal.

Kobayashi, K., Ohnishi, A., Sasaki, D., Fujii, S., Iwase, A., Sugimoto, K., Masuda, T., \& Wada, H. 2017. Shoot removal induces chloroplast development in roots via cytokinin signaling. Plant Physiology, 173, 2340-2355.

Nurlaeni, Y. dan M.I. Surya. 2015. Respon stek pucuk Camelia japonica terhadap pemberian zat pengatur tumbuh organik. Pros Sem Nas Masy Biodiv Indon. 1 (5): 1211-1215.

Rahman, M., Karno, dan B. A. Kristanto. 2017. Pemanfaatan Tanaman Kelor (Moringa oleifera) Sebagai Hormon Tumbuh Pada Pembibitan Tanaman Tebu (Saccharum officinarum L.). J. Agro Complex 1(3): 94-100

Salisbury dan Ross, 1995. The Flower Process. Pumaon Press, Oxfand London.

Santoso, U dan Nursandi F. 2002. Kultur Jaringan Tanaman. UMM Press. Malang. 
Taiz, L., \& Zeiger, E. (2002). Plant physiology and development (3rd ed.). Sinauer Associates, Inc., Publishers. Sunderland, Massachusetts.

Tanaka, R., Kobayashi, K., \& Masuda, T. 2011. Tetrapyrrole metabolism in Arabidopsis thaliana. Arabidopsis Book. 